\title{
SSynthesis
}

International Scientific Conference of IT and Business-Related Research

\section{DEVELOPMENT OF FREE SOFTWARE APPLIED TO EDUCATION AND RESEARCH}

\author{
RAZVOJ BESPLATNOG SOFTVERA ZA PRIMENU \\ U OBRAZOVANJU I ISTRAŽIVAČKOM RADU \\ Juan Ruiz-Ramírez'1, Gabriela Eréndira Hernández-Rodríguez¹, Christian Pérez-Salazar², \\ Miriam de los Ángeles Díaz-Córdoba ${ }^{3}$, Rafaél Vela Martínez ${ }^{4}$ \\ ${ }^{1}$ Facultad de Economía, Universidad Veracruzana. Av. Xalapa s/n esq. Ávila Camacho. 91020. Xalapa, Veracruz México \\ ${ }^{2}$ Instituto de Investigaciones Multidisciplinarias \\ ${ }^{3}$ Facultades de Pedagogía y Derecho \\ ${ }^{4}$ Instituto de Investigaciones y Estudios Superiores Económicos y Sociales, Universidad Veracruzana. México
}

\begin{abstract}
:
The current economic crisis in Mexico has resulted in budget reductions allocated to public universities, which also limits the purchase of commercial software licenses. The use of different types of software is necessary for the application of Information and Communication Technologies (ICT), and their absence at higher education institutions (UEI) impedes the preparation of undergraduate students, which has adverse effects on the professional performance and the overall quality of employment. Bearing in mind the above-stated, the aim of this paper is to develop free software that can be applied to education and research. The generation of software "EficienciaRelativa", "MuestreosEstadísticos", and "GEGasolinas2.0", made use of Java programming language. While the first one calculates the efficiency of experimental designs, the second one determines the sample size, while the third one calculates the generation of gasoline consumption scenarios and production of bioethanol fuel from sugar cane. They have been used to support education and research and contribute to reducing the digital divide and enhancing graduation rates and the overall quality of education at Mexican UEIs.
\end{abstract}

\section{Key words:}

applied informatics, statistics, bioethanol scenarios, digital gap, Mexico.

\section{INTRODUCTION}

Mexico has undergone the economic crisis on several occasions, which has resulted in a noticeable decrease of the economic growth rate in the country and increase in the poverty and inequality rate between regions. In this context, the allocation of public resources through the Expenditures Budget of the Federation (EBF) in strategic areas of national development has become of vital importance for inverting socio-economic issues inherent to the Mexican economy. The two fundamental areas within the national economic development are education and research, as pointed out by the Organization for Economic Cooperation and Development (OECD): To invest in education today is more important than ever as it will allow responding to demographic and technological changes affecting the labor market (OECD, 2010). Nonetheless, the related budget allocations in this respect are too low compared to other countries in the region and the rest of the world. While Mexico spends $5.7 \%$ of the domestic income on the educational system, Chile allocates $6.4 \%$ of its public funds to education, and Brazil $5.2 \%$. On the other hand, the annual expenditure on higher education still remains low, amounting to only $\$ 7,899$ per annum

\section{Apstrakt:}

Aktuelna ekonomska kriza u Meksiku dovela je do smanjenja budzetskih sredstava namenjenih državnim univerzitetima, što takođe ograničava kupovinu softvera sa komercijalnim licencama. Upotreba različitih tipova softvera neophodna je u primeni informacionih i komunikacionih tehnologija (IKT) i njihovo odustvo na visokoobrazovnim institucijama ima negativni uticaj na profesionalni učinak i sveukupan kvalitet rada zaposlenih. Shodno tome, cilj ovog rada jeste da se razvije besplatan softver koji se može primeniti u obrazovanju i istraživačkom radu. Autori opisuju softvere "Eficiencia Relativa", "Muestreos Estadísticos", i "GEGasolinas2.0", koji se služe Java programskim jezikom. Naime, prvi izračunava efikasnost eksprimentalnog dizajna, drugi određuje veličinu uzorka, dok se treći bavi izračunavanjem potrošnje benzina i proizvodnjom bioetanola od šećerne trske. Njihova primena je prvenstveno usmerena ka obrazovanju i istraživačkom radu, ali i smanjenju digitalnog jaza i povećanju stope diplomiranih studenata i kvaliteta obrazovanja na visokoobrazovnim institucijama u Meksiku.

\section{Ključne reči:}

primenjena informatika, statistika, bioetanol, digitalni jaz, Meksiko.

per student. This is less than one third of what the US spends on the same segment $(\$ 26,000)$, while Brazil spends $\$ 10,905$ annually per student, and Chile invests $\$ 8,333$ per a university student. Conversely, the registration of students (undergraduate and graduate) in Brazil is in the order of 5 million students, 1 million in Chile, and 2.3 million in Mexico (OECD, 2014). If one takes into consideration that the total expenses per student in the domain of higher education for the three first countries in the comparative table of the OECD goes to Denmark with an accrued amount of $\$ 110,520$ in 5.2 years, Switzerland with $\$ 93,890$ in 4.5 years, and Holland with $\$ 92,310$ in 5.3 years. In this analysis, Mexico is the second to last with the expense of $\$ 26,428$ in an average of 3.3 years. This means that the accrued expense per student in Mexico equals to the expense in US per student in only one year.

As regards expenditures in research and development, it represents barely $0.48 \%$ of the GDP, in relation to the OEDC average, which is $2.34 \%$. The government spends somewhat 60,000 million Mexican pesos a year on research and development, whereas private companies spend approximately 40,000 million Mexican pesos a year. The recommendation is to increase the investment by $500 \%$ in order to reach the desirable level 
to induce the economic development. According to the World Development Indicators (2014), Mexico has 386 researchers per million of inhabitants, while in Finland, they occupy the first place in the list, with 7,482 researchers per million inhabitants, or Brazil with 710 researchers per million inhabitants. In 2011, Mexico published 4,128 scientific divulge articles, Brazil contributed with 13,148 articles, while the US assumed the first position with a volume of 208,601 articles.

The use of IT in UEI allows the students to increase their labor efficiency and the quality of their employment. However, a limitation of commercial software is that it is not possible to acquire several licenses at a time, and in the particular case of relative efficiency in experimental designs, one cannot know if the design was properly applied and the results reported in the variance analysis, as in such case, specific software has to be developed. As regards software in the area of sampling, one can get free or commercial software, but as the source code is obviously not included, one cannot manipulate or modify the program. A particular case was that of the software "GEGasolinas 2.0" or projection of scenarios, which does not exist in a commercial version.

Another problem in higher education is the so called digital gap, defined by (Terceiro \& Matias, 2001) as the distance between those who have and those who do not have access to IT. Ugas and Cendros (2005) defined it as the distance towards the opportunities to use IT; and the Commission for Studies for Latin America (CEPAL) (cited in Tello, 2008) views it as the difference between the rich and the poor in information. In order to increase the quality of education, Open Educational Resources (OER) must be used. This concept was used by UNESCO at the First World Forum on free access education resources and is described as educational and material resources that can be re-utilized for teaching-learning purposes at no cost (UNESCO, 2002).

An example of free and proprietary software can be reviewed at $h t t p s: / / s e r a p 97 . f i l e s . w o r d p r e s s . c o m / 2012 / 11 / a p p 2 . p n g$. Another comparison between Windows Software and Linux Software can be reviewed at http://www.linuxscrew.com.

As regards the importance of information and communication technologies and free software development, a goal has been set to develop free software applied to education and research."

\section{METHODOLOGY}

Academician from different institutions within Universidad Veracruzana have been working for 5 consecutive years on creating a multi-disciplinary work group with the aim to respond to diverse academic needs, with an emphasis on the development of computational tools that should provide support to the teaching and research process, whether to automate processes that are time-consuming or as support to the decision making process, due to the difficulty in finding or acquiring software that could meet such needs (Pérez-Salazar et al., 2014).

According to Ramirez and collaborators (2011), we live in an era where we are no longer just simple users (of systems, applications, services, etc.), but also creators of our own digital contents. This is to go further than only consume and collaborate, in order to be capable of creating products that can be useful for the academic community. Based on these notions, we also believe that these developments must be made available to everyone (apart from being free), by allowing those who possess the required knowledge to modify its source code, thinking always on its improvement.
All of the developments that we made during these years have been through the programing language JAVA which is a general purpose language competitor, based on lessons and object-oriented (Gosling et al., 2015). It is primarily focused on two aspects: 1) previous knowledge of the members of the workgroup about this language and, 2) the fact that is one of the most widely spread languages in the world (TIOBE, 2015; Nanz \& Furia, 2015).

Due to the multidisciplinary nature of the members of the workgroup, it was necessary to look for the ways to develop programs needed within the shortest possible time, without everyone been thoroughly familiar with the stages of software development that agile or traditional methodologies indicate. Owing to this, it was decided to attempt to implement the ideas and Scrum's principles (mainly responsibility, self-demanding and self-organization) according to the needs and abilities of the workgroup's members. Scrum is an agile project management methodology used for software development projects, which aims to offer results within two to four weeks' time (VersionOne, 2015). Moreover, according to the research sponsored by VersionOne (2014), Scrum or Scrum variants are by far (73\%) the agile methodology most frequently used for software development worldwide, as shown in Figure 1.

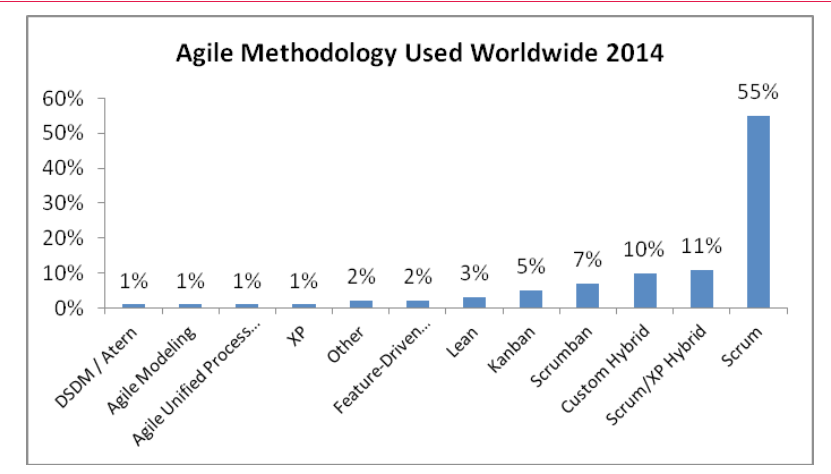

Figure 1. Results of the survey by Version One regarding the agile methodologies used worldwide.

Source: Version One (2014).

\section{RESULTS}

Some of the results obtained when working with the Scrum process when generating open and free software can be exemplified with the Software "Eficiencia Relativa" (Figure 2), which is useful in Experimental Design courses or in ANOVA topics for the purpose of evaluating whether the experimental design is appropriate compared to another experimental design that is less complex (Ruiz-Ramírezet al., 2012). This software is also useful in agricultural research and in various other disciplines, including quality control.

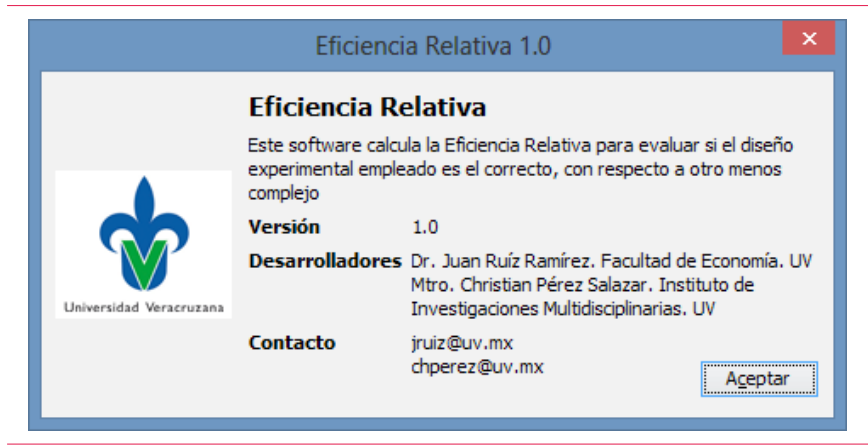

Figure 2. Software "Eficiencia Relativa” Description and developers. 
"Muestreos Estadísticos" Software (Figure 3) (Ruiz-Ramírez et al., 2014a) is useful when carrying out the analysis to determine whether it is necessary to generate data through primary sources, in addition to the fact that this topic is studied within Methodology or Research Seminary courses and is used in the descriptive type of research.

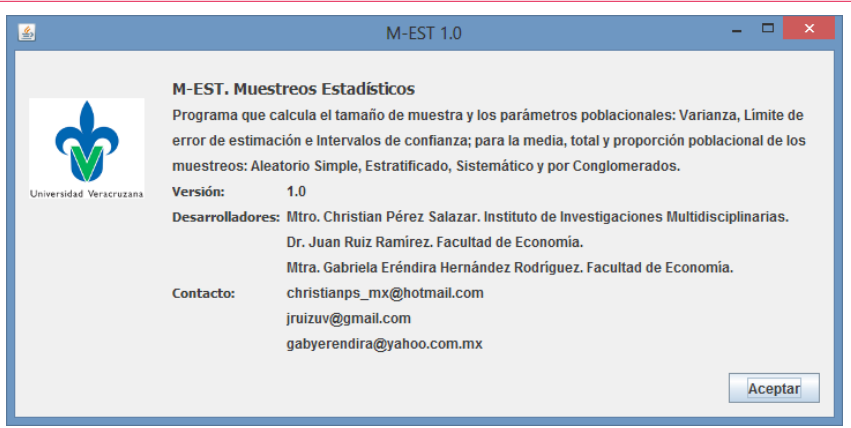

Figure 3. "Muestreos Estadísticos" Software Presentation and Description

As regards the "Generador de Escenarios V2.0" software, it functions as support to the decision making process in the field of biofuel production in Mexico, because it can easily produce projections/statistics of the national consumption and imported fuels from Mexico and it also offers strategies for saving millions of dollars with the substitution of these importations to the production of ethanol, the latter being presented in several academic forums (Ruiz-Ramírez et al., 2006; Pérez-Salazar et al., 2011; Ruiz-Ramírez et al. 2011). Figure 4 shows the screenshot of the latest version of the program.

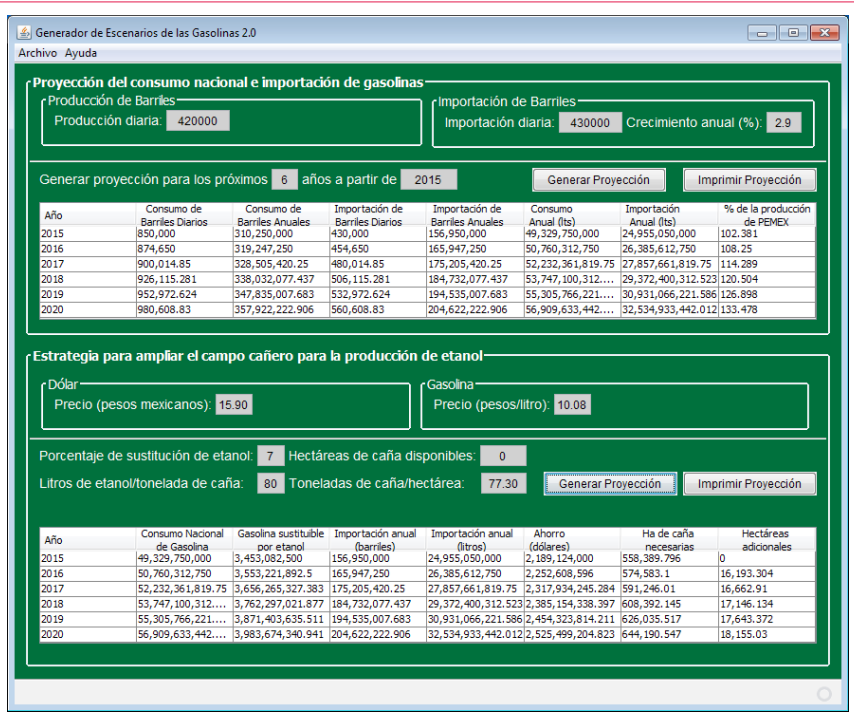

Figure 4. Screenshot of the "Generador de Escenarios de las Gasolinas" program.

The results shown in Figure 4 are useful in the decision making process, primarily in the public policies of Mexico. Moreover, it is a very common phenomenon that publications in agricultural magazines do not analyze whether the experimental design was the appropriate, which is why the results given can be seen as incorrect. Even though it is fairly usual to use secondary sources of information in the research processes, the liability of the information of the official sources (Ruiz-Ramírez et al., 2014b) is not granted, also given the fact that not all the information is registered or required. That is why it should be directly generated and here the methods of probabilistic sampling and the "Muestreos Estadísticos" software are greatly useful for estimating the sample's size and the punctual parameters or with a confidence interval.

As regards the digital divide, professors have to bridge the distance and inequality gap, by giving access to the students to gain better opportunities. Therefore, they should keep up to date with both their field of expertise and pedagogical strategies (Salado, 2011). A better preparation shall enable the use and harnessing of the "REA", besides the enrichment of education processes, and it will allow for a collaborative work and contribute to the development of competences (Ramírez \& Mortera, 2009).

In the usage of Information and Communication Technologies applied to education and research, previously mentioned open and free software can be modified and necessary innovations implemented, without the consent of its developer, contrary to Cardoza's statements (2008). As regards the access to free resources, Ramírez and Mortera (2009) believe that it should have academic criteria as well as copyrights with international standards; that is why "Eficencia Relativa" and "Muestreos Estadísticos" software have copyrights in Mexico and the "Generador de Escenarios V2.0" software is currently in the process of registering copyrights.

These ICTs have become widely spread in the area of economics, informatics and sadistic, and agricultural sciences, as well as in the domain of Ph.D. studies of Public Finances at the Universidad Veracruzana. Also, open software were presented at the XXIX Statistics International Forum and at the first International Scientific Conference UCIENCIA at Havana, Cuba. It is expected from ICTs to enhance the quality of education at higher education institutions in Mexico, and 3,174,801 students belonging to the 2342 schools at bachelor's degree and technological university degree are expected to benefit from such enhancement (Statistical Yearbook of Higher Education Bachelor degree 2013 of the ANUIES [http://www.anuies.mx/ content.php?varSectionID=166], in addition to the increasing of the terminal efficiency of the $50 \%$.

\section{CONCLUSIONS AND RECOMMENDATIONS}

It can be concluded that open software development applied to education and research includes Information and Communication Technologies that contribute to the improvement of the quality of education and decrease the digital divide.

It is recommended to perform a case and control study, and the evaluation of grades obtained in a thematic unit, especially where open software was used to support the teaching process at higher education institutions.

\section{REFERENCES}

Cardoza Barreto, G. (2008). Tecnologías de la Información y la Comunicación en la Educación. Un punto de vista para discusión. Revista Iberoamericana de Educación que EDITA: Organización de Estados Iberoamericanos para la Educación, la Ciencia y la Cultura (OEI), 45, 1-25.

Gosling, J., Joy, B., Steele, G., Bracha, G., \& Buckley, A. (2015). The Java Language Specification.Java SE 8 Edition. Retrieved March 5, 2015 from http://docs.oracle.com/javase/ specs/jls/se8/jls8.pdf

Nanz, S., \& Furia, C.A. (2015). A Comparative Study of Programming Languages in Rosetta Code. Retrieved March 5, 2015 from http://arxiv.org/pdf/1409.0252.pdf 
OCDE. (2010). Panorama de la educación 2010. Elementos clave sobre la educación en México.

OCDE. (2010). Elementos clave sobre el estado de la educación en México. Retrieved March 15, 2015 from http://www.oecd. org/centrodemexico/medios/panoramadelaeducacion2010. htm

OECD. (2014). Mexico - Country Note - Education at a Glance 2014. Retrieved March 15, 2015 from http://www.oecd.org/ edu/Mexico-EAG2014-Country-Note.pdf.

Pérez-Salazar, C., Cortés-García, R., Cruz-Hernández, E., \& Cortés-Lara, M.A. (2011). Modelo de cálculo en diferentes proporciones de Etanol en mezcla con las Gasolinas en México. XXXIII Convención Nacional ATAM “Ing. Ignacio Gurza Iglesias” El Cambio Climático, Responsabilidad de Todos. Boca del Río, Veracruz, México. 21 de Septiembre de 2011.

Pérez-Salazar, C., Ruiz-Ramírez, J., \& Barcelata-Chávez, H. (2014). El espíritu de SCRUM en el desarrollo de software libre en el ámbito académico. En Atlante. Cuadernos de Educación y Desarrollo. Retrieved March 15, 2015 form http://atlante. eumed.net/scrum-software/

RamirezMartinell, A., Fraire Quiroz, J., Montes Reyes, D., Oliva Mesa, O. G., García Esqueda, G., Mayo Castelán, S. D., Cornelio Vidal, I. G., Cruz Soto, M., Olan Cobos, S. J. (2011) Diseño de imagen digital con software libre. Red Iberoamericana para el Desarrollo Sustentable, A.C. México.

Ramírez, M.S., \& Mortera, J.F. (2009). Implementación y Desarrollo del Portal Académico de Recursos Educativos Abiertos (REAs): KnowledgeHub para Educación Básica. Memorias de congreso de la Red de Posgrados en Educación. Guanajuato, Guanajuato.

Ruiz-Ramírez, J., Bravo-Garzón, R., \& Pérez-Salazar, C. (2006). Aplicación de software que proyecta la producción de la caña de azúcar y el uso de etanol como combustible en México. XVI Coloquio Mexicano de Economía, Matemática y Econometría. Xalapa, Veracruz, México.

Ruiz-Ramírez, J., Pérez-Salazar, C., \& Hernández-Rodríguez, G.E. (2011). Actualización del software que proyecta la producción de la caña de azúcar y el uso de etanol como combustible en México. $16^{\circ}$ Encuentro Nacional sobre Desarrollo Regional en México, AMECIDER 2011. Xalapa, Veracruz, México.
Ruiz-Ramírez, J., Pérez-Salazar, C., Cruz-Kuri, L., \& HernándezRodríguez, G.E. (2012). Programa que calcula la eficiencia relativa de los diseños experimentales. Terra Latinoamericana, 30(1), 97-100.

Ruiz-Ramírez, J., Pérez-Salazar, C., \& Hernández-Rodríguez, G.E. (2014a). Aplicaciones de software libre en la enseñanza de la estadística en las IES en México. I Conferencia Científica Internacional. UCIENCIA 2014. La Habana, Cuba.

Ruiz-Ramírez, J., Fortuno Hernández, J.C., \& Rafael Vela Martínez, R. (2014b). Ética y estadística en la generación y aplicación del conocimiento en: Ética en la práctica profesional (Coord. Ruiz-Ramírez, J., Díaz Córdoba, M.A. y Fortuno Hernández, J.C.). México: Universidad Veracruzana.

Salado, Rodríguez L.I. (2011). Contribución de los recursos educativos abiertos al aprendizaje significativo de las tecnologías de información y comunicación en el estudiante universitario. Revista Internacional Administración \& Finanzas, 4(1), 101-114.

Tello, Leal E. (2008). Las tecnologías de la información y comunicaciones (TIC) y la brecha digital: su impacto en la sociedad de México. Revista de universidad y sociedad del conocimiento. 4 (2).

Terceiro, J., \& Matías, G. (2001). Debates: Información, tecnología y desarrollo. México: Taurus.

TIOBE Programming CommunityIndex. Retrieved March 15, 2015 from http://www.tiobe.com

Ugas, L., \& Cendrós, J. (2005). Brecha digital en la difusión de la tecnología de Internet para el acceso a la Sociedad Red. Revista de CienciasSociales, 11(2), 296-310.

UNESCO (2002).Forum on the impact of open courseware for higher education developing countries.Final report. Paris.

VersionOne. (2014). 8th Annual State of Agile Survey. Retrieved March 15, 2015, from http://www.versionone.com/pdf/2013state-of-agile-survey.pdf

World Bank. (2014). World Development Indicators Retrieved March 15, 2015 from http://data.worldbank.org/sites/default/files/wdi-2014-book.pdf 